Original Research Article

\title{
Seasonal variations of phytoplankton in Mohabala Lake near Bhadrawati, District - Chandrapur (MS), India
}

\author{
Mahajan, V. S.
}

Department of Zoology, Nilkanthrao Shinde Science \& Arts College, Bhadrawati, Dist. Chandrapur,

Maharashtra, India

Corresponding Author: badkhalvm@gmail.com

\author{
A R T I C L E I N F O \\ Received: 19 January 2018 | Accepted: 22 April 2018 | Published Online: 15 August 2018 \\ DOI: $10.31786 / 09756272.18 .9 .1 .114$ \\ EOI: 10.11208/essence.18.9.1.114 \\ Article is an Open Access Publication. \\ This work is licensed under Attribution-Non Commercial 4.0 International \\ (https://creativecommons.org/licenses/by/4.0/) \\ CThe Authors (2018). Publishing Rights @ MANU_ICMANU \& ESSENCE-IJERC.
}

\section{A B S T R A C T}

Among the biotic communities in an aquatic system phytoplankton constitute the major role by virtue of their capacity to transducer the solar radiant energy into thebiological energy by photosynthesis. A study was carried out in Mohabala lake on phytoplankton diversity in different seasons during 20142015. The Mohabala lake is principal fresh water body located within Bhadrawati Tahsil in Chandrapur District of Maharashtra state. The four major groups of phytoplankton studied are Chlorophyceae, Cyanophyceae, Bacillariophyceae and Euglenophyceae. During this investigation phytoplankton shows abundance growth in winter and minimum in monsoon .

\section{K E Y W O R D S}

Seasonal | Phytoplankton | Mohabala lake

\section{I T A T I O N}

Mahajan, V. S. (2018): Seasonal variations of phytoplankton in Mohabala lake near Bhadrawati, district - Chandrapur (MS), India. ESSENCE Int. J. Env. Rehab. Conserv. IX (1): 117-123. 


\section{Introduction}

Phytoplanktons are the autotrophic component. They primary producers of aquatic ecosystem form the primary level of the aquatic food chain. Phytoplankton form food for zooplankton, fishes and other aquatic animals. They also play very important role by regulating the level of dissolved oxygen which necessary gas for aquatic life (Sudhakara, 2012). In fresh water body phytoplanktons consist of macroscopic and microscopic suspended or free floating non motile or weekly motile unicellular, colonial or filamentous algae. Algae are used to assess ecological health of aquatic habitats (Matta, 2010). Ryder et al., (1974) pointed that the majority of members belong to Chloropyceae, Cyanophyceae, Bacillariophyceae and Euglenopyceae.

Phytoplanktons are the base of most of the lakes food web and fish productions is linked to phytoplanktons production. The number and species of phytoplankton helpful to determine the quality of water body. Phytoplankton are very sensitive to eutrophication so useful for detection of eutrophication of water and it's adverse impact on the aquatic ecosystem and plays a very important role in regulating the dynamics of the aquatic food web and become a driving force in shaping the community structure of zooplanktons (Xie et. al., 1998). Phytoplanktons, diversity, biomass, density, seasonal variation and species distribution have been largely affected by a number of abiotic properties of water, water body morphology, sewage discharge and human activities (Matta, 2015; Matta et al., 2015).

\section{Material and Method}

The water samples were collected from the three sites of lake such as site A, site B and site C. The samples were collected in the morning hours between 8.30 to 10.30 a.m. 50 lt. of water sample was filtrated through the plankton net made of bolting silk number 25 with mesh size 64 lime. The collected samples were allowed to settle down by adding Lugol's iodine. Sedimentation requires $24 \mathrm{hrs}$ after which supernatant was removed and concentrate was made up to $50 \mathrm{ml}$ depending the number of plankton and preserved in $5 \%$ formalin for further studies. For the quantitative study, the concentrated sample was shaken and one drop of sample was taken on a clear micro slide with the help of a standard dropper, the whole drop was carefully covered with the cover glass and observed. Plankton identification up to genera and whenever possible up to species level was classified according to keys given by Edmonson (1959), Adoni (1985) and APHA (1985) and standard analysis was undertaken as per Zar (2005).

Quantitative study of plankton was done by Sedgwick - Rafter Cell method.

The Sedgwick Rafter Cell is a special kind of slide similar to the Haemocytometer. The cell has a $50 \mathrm{~mm} \times 20 \mathrm{~mm} \times 10 \mathrm{~mm}$ rectangular cavity that holds $1 \mathrm{ml}$ sample. The cell is moved in horizontal directions on the stage of an inverted microscope and planktonic species encountered in the field are enumerated. A number of replicate samples are enumerated to calculate plankton / lit.

Plankton (Units /lit.) $=\mathrm{nx} \mathrm{c/v}$

Where, $\mathrm{n}=$ number of plankton in $1 \mathrm{ml}$.

$\mathrm{c}=$ volume of concentrate.

$\mathrm{v}=$ volume of sample in lit.

\section{Result and Discussion}

During the present investigation, maximum of phytoplanton density was recorded in site $\mathrm{A}$ and minimum in site $\mathrm{C}$ followed by site B. During present study phytoplankton shows maximum growth in winter and minimum in monsoon in all three sites A, B, and C of the lake. The maximum density of phytoplankton during winter season have also been observed by Chakraborty et. al., (1959) and Pahwa and Mehrotra (1966) in river Jamuna and Ganga river.

The four major groups of phytoplankton studied are Chlorophyceae, Cyanophyceae, Bacillariophyceae and Euglenophyceae. Among these four groups Chlorophyceae was dominant in site A and site $\mathrm{B}$ and site $\mathrm{C}$ of Mohabala lake. During present investigation phytoplankton shows abundance growth in winter and minimum in monsoon in all three sites A, B and C of the lake. Palmer (1969) has noted that the genera like Euglena, Oscillatoria, Scenedesmus, Microcystis, Navicula 
and Chlorella were found in organically polluted water, similar were of the opinion by Goel et al., (1985) and similar genera were recorded during the present study.

\section{Site A}

In Chlorophyceae 24 species were recorded are among which Ankistrodesmus sp. (412 no./lit) was dominant followed by Cladophora sp. (406 no./lit.), Chlorella sp. (330 no./lit.), Chara sp. (154 no./lit.), Cosmariumgranatum (153 no./lit.), Coelastrumchodati (143 no./lit.), Chlamydomonas sp. (143 no./lit.), Spirogyra sp. (104 no./lit.), Euastropsisrichteri (103 no./lit.), Hydrodictyon sp. (94 no./lit.), Pleurodiscus sp. (94 no./lit.), Netriumdigitus (91 no./lit.), Pediastrum tetras (85 no./lit.), Staurastrum sp. (82 no./lit.), Nitella (79 no./lit.), Trochisciapachyderma (76 no./lit.), Micrasteriaspinnatifida (74 no./lit.), Closteridiumlinula (62 no./lit.), Goniochloris sp. (56 no./lit.), Nitella sp. (49 no./lit.), Cylindrospermum sp. (44 no./lit.), Gloeocystisgigas (44 no./lit.), Spirogyra sp. (43 no./lit.) and Micrasteriaspinnatifida (41 no./lit.).

In Bacillariophyceae 11 species were recorded among which Synedra ulna (601 no./lit.) was dominant followed by Pinnularia sp. (224 no./ lit.),Navicularadiosa (157 no./lit.), Bacillariaparadoxa (84 no./lit.), Nitzschiasigmoidea (79 no./lit.), Gyrosigmakutzingii (73 no./lit.), Cocconeisplacentula (65 no./lit.), Anomoeoneissphaerophora (54 no./lit.), Pinnularia sp. (28 no./lit.),Diotoma sp. (25 no./lit.) and Cyclotella sp. (20 no./lit.).

In Euglenophyceae the three species were recorded among which Phacus sp. (833 no./lit.) which was dominant followed by Euglena acus (462 no./lit.) and Peranematrichophorum (113 no./lit.).

In Cynophyceae eight species were recorded among which Microcystis sp. (258 no./lit.) was dominant followed by Oscillatoria sp. (173 no./ lit.), Gleotrichiaechinulata (155 no./lit.), Nostoc sp. (123 no./lit), Anacystiscyanea (91 no./lit.), Agmenellumquadruplicatum (83 no./lit.), Anabaena sp. (71 no./lit.) and Coelastrumpolychor$\operatorname{dum}(68$ no./lit.).

\section{Site B}

In Chlorophyceae 16 species were recorded among which Ankistrodesmus sp. (254 no./lit.) was dominant followed by Chlorella sp. (188 no./ lit.), Cosmariumgranatum (128 no./lit.), Chara sp. (96 no./lit.), Chlamydomonas sp. (94 no./lit.), Coelastrumchodati (20 no./lit.), Netriumdigitus (82 no./lit.), Euastropsisrichteri (78 no./lit.), Pleurodiscus sp. (65 no./lit.), Pediastrum tetras (62 no./lit.), Nitella sp. (60 no./lit.), Goniochloris sp. (41 no./lit.), Goniochloris sp. (38 no./lit.), Micrasteriaspinnatifida (37 no./lit.), Glaeocysticgigas (29 no./lit.) and Closteridiumlinula (20 no./ lit.).

In Bacillariophyceae 11 species were recorded among which Synedra ulna (390 no./lit.) was dominant followed by Navicularadiosa(150 no./ lit.), Rhopalodiagibba(132 no./lit.), Bacillariaparadoxa (79 no./lit.), Cocconeisplacentula (66 no./lit.), Gyrosigmakutzingi (63 no./lit.), Anomoeoneissphaerophora (57 no./lit.), Nitzschiasigmoidea (53 no./lit.), Diatoma sp. (29 no./ lit.),Cyclotella sp. (24 no./lit.) and Pinnularia sp. (31 no./lit.).

In Euglenophyceae three species were recorded Phacus sp. (516 no./lit.) was dominant followed by Euglena acus (310 no./lit.) and Peranematrichophorum (147 no./lit.).

In Cynophyceae six species were recorded among which Microcystis sp. (286 no./lit.) was dominant followed by Oscillatoria sp. (162 no./lit.), Nostoc sp. (123 no./lit.), Anacystiscyanea (97 no./lit.), Anabaena sp. (65 no./lit.) and Agmenellumquadruplicatum (39 no./lit.).

\section{Site C}

In Chlorophyceae 20 species were recorded among which Cladophora (276 no./lit.) was dominant followed by Ankistrodesmus sp. (262 no./ lit.), Chorella sp. (206 no./lit.), Coelastrumchodati (119 no./lit.), Chlamydomonas sp. (100 no./lit.), Closteridiumlinula (95 no./lit.), Chlorococcumhumicola (94 no./lit.), Chara sp. (91 no./lit), Spirogyra sp. (82 no./lit.), Nitella sp. (78 no./lit.), Troschisciapachyderma (69 no./lit.), Pleurodiscus sp. (62 no./lit.),Hydrodictyon sp. (60 no./lit.), Pe- 
Microsteriaspinnatifida (21 no./lit.). In Bacillariophyceae 11 species were recorded among which Synedra In Euglenophyceae two species were recorded among which Phacus sp. (417 no./lit.) was followed by Euglena acus (278 no./lit.).

The presence of pollution indicator species of chlorophyceae like Ankistrodesmus sp., Spirogyra sp. as pollution indicator species shows that the site A is eutrophic and site B is moving towards eutrophication. A. B. Sarwade and N. A. Kamble (2013) observed major species as Chlorella sp., Ankistrodesmus sp., Spirogyra sp., in Bharatnagar lake of Miraj Tahsil District Sangli Maharashtra. M.R. Abdar (2013) reported presence of organic pollution indicator algal species like Ankistrodesmusfalcatus, Chlorella vulgaris in Morna lake Shirala (M.S.).

In the present investigation, Chlorophyceae was found maximum during the winter season and minimum during the monsoon season. Jayabhaye et. al., (2007) observed maximum Chlorophyceae population during the summer and minimum during the rainy season in Parola dam of Hingoli, Maharashtra. Malik and Bharti (2012) revealed that Chlorophyceae was maximum during the winter season and minimum during the monsoon season in Sahastradhara stream at Uttarakhand.

In the present investigation, Chlorophyceae was found maximum during the winter season may be due to high amount of dissolved oxygen and minimum during the monsoon season may be due to low temperature and dilution due to rain water. Dissolved oxygen shows positive correlation with Chlorophyceae species. Banaker et al., (2005) observed several pollution indicator species of Bacillariophyceae from Chandravalli tank at Chitradurga, Karnataka. Devi and Antal (2013) also recorded presence of water pollution indicator species as Nitzchia sp., Synedra sp., Diatomasp. in Temple pond in Birpur ( $\mathrm{J}$ and $\mathrm{K})$. Jindal and Gussain (2007) observed Naviculla sp. and Nitzschiasp. as a pollution indicator species of Bicholli pond of Rajasthan.

In the present investigation the maximum density of Bacillariophyceae was recorded during the summer season due to high temperature, high tempera- ture favours the luxuriant growth of Bacillariophyceae and may be due to the site which is rich in organic matter and minimum density of Bacillariophyceae in rainy season at site B due to sudden fall of temperature, more human activities and dilution of water by rain water.

In the present investigation, the dominance of Microcystis sp. and Oscillotoria sp. in site A and site $\mathrm{B}$ and site $\mathrm{C}$ showed the polluted nature of the three sites which shows lake is highly polluted.

In the present investigation, Cyanophyceae was maximum during the winter season and minimum during the monsoon season. Pendse et. al., (2000) recorded the maximum population of blue-green algae during winter. In the present investigation, the maximum amount of Cyanophyceae during the winter is due to favorable sunlight, increase in domestic sewage, human generated pollution, while minimum quantity during the monsoon is probably due to increase in water quantity.

\begin{tabular}{|c|c|c|c|c|c|}
\hline$\stackrel{\bar{\sigma}}{\stackrel{\sigma}{\theta}}$ & 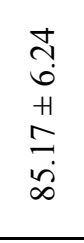 & $\begin{array}{l}\infty \\
\infty \\
\infty \\
+ \\
+ \\
\infty \\
\infty \\
\dot{o} \\
\stackrel{+}{\sim}\end{array}$ & 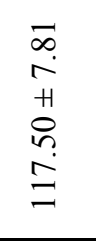 & $\begin{array}{l}\stackrel{ }{\exists} \\
\dot{0} \\
+1 \\
m \\
\cong \\
=\end{array}$ & \\
\hline 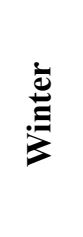 & 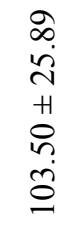 & 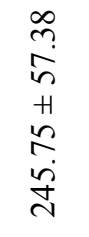 & 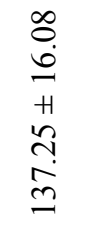 & 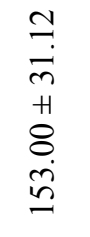 & \\
\hline 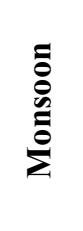 & 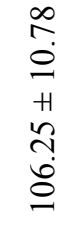 & 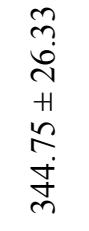 & $\begin{array}{l}\hat{\infty} \\
\dot{a} \\
+ \\
\dot{0} \\
0 \\
\dot{\sigma}\end{array}$ & 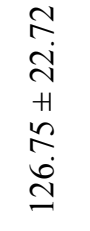 & \\
\hline $\begin{array}{l}\stackrel{\bar{\Xi}}{\Xi} \\
\text { E }\end{array}$ & 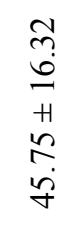 & $\begin{array}{l}\hat{n} \\
\stackrel{1}{1} \\
+1 \\
8 \\
0 \\
\stackrel{0}{n}\end{array}$ & 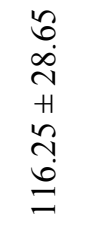 & 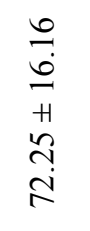 & \\
\hline 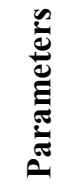 & 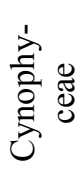 & 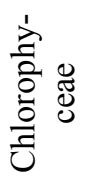 & 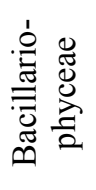 & 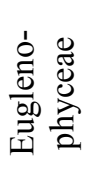 & \\
\hline$Z_{\dot{\infty}} \dot{0}$ & - & $N$ & $m$ & $\checkmark$ & \\
\hline
\end{tabular}




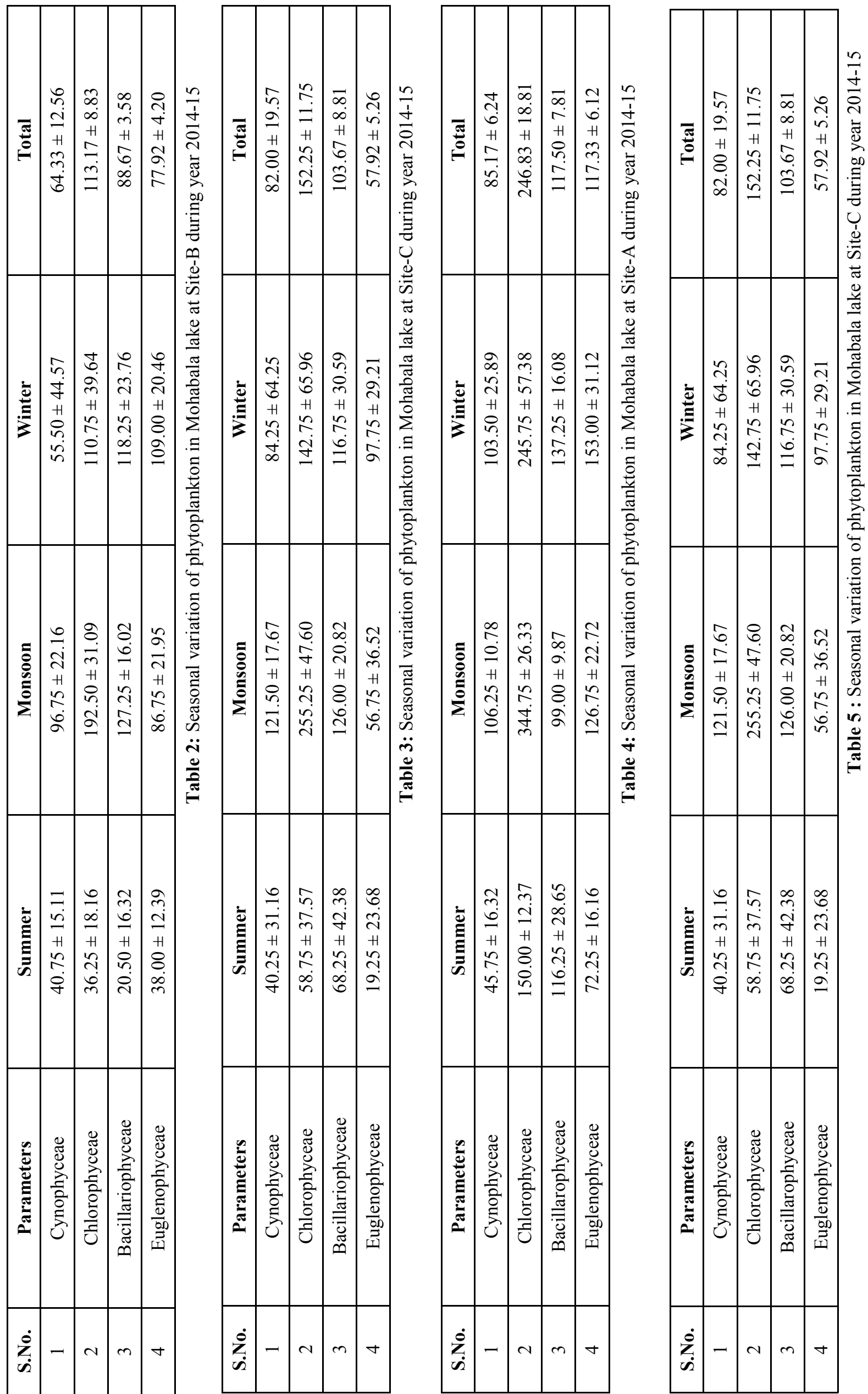




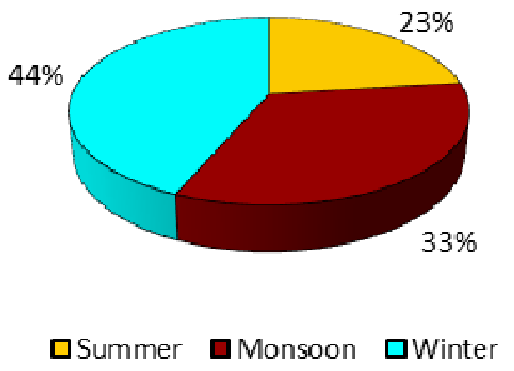

Fig. 1: Distribution of Phytoplankton in Site A during the period 2014-15

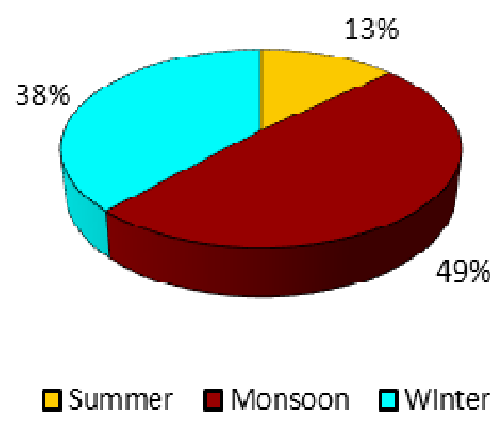

Fig. 2: Distribution of Phytoplankton in Site B during the period 2014-15

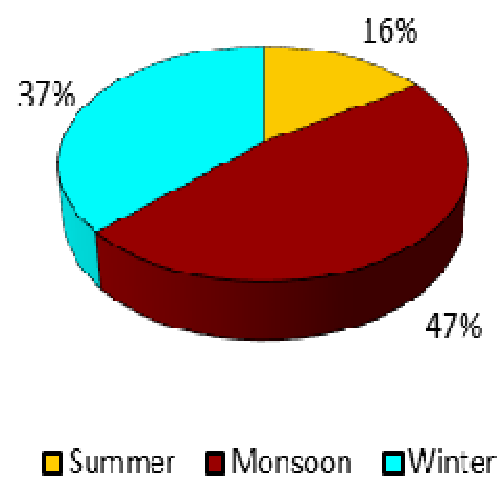

Fig. 3: Distribution of Phytoplankton in Site C during the period 2014-15

Alam and Khan (1996) stated that the occurrenceof Euglena sp. and Phacus sp. are a direct indication of beginning of pollution load because both these species in generally, considered to bedominant and tolerant genera of polluted pond. Palmer (1969) has reported that the Euglenophyta are the biological indicators of organic pollution. In the present investigation, Euglenophyceae are greater in number which is organically polluted water and contaminated with organically rich effluents. In the present investigation the maximum Euglenophyceae during the winter season may be due favorable water temperature and minimum in rainy season due to dilution of water by rain water.

Presence of pollution tolerant species of phytoplankton species shows that the Mohabala lake is highly polluted.

\section{Acknowledgement}

I am very thankful to Dr. Narendra Harney for his invaluable guidance.

\section{References}

Devi, Aarti and Antal, Neha (2013): Variation in phytoplankton diversity and its relationship with abiotic environment of a Temple pond in Birpur (JandK) India. Universal Journal of Environmental Research and Technology, 3(2): 181-189.

Abdar, M. R. (2013): Physico-chemical characteristics and phytoplankton of Morna lake, Shirala (M.S.), India. Biolife an international quarterly journal of biology and life science, 1(2): 1-7.

Adoni, A. D. (1985): Work book on limnology, Dept. of Environment, Govt. of India, Bandana printing service, New Delhi, 88 .

Alam, A. and Khan, A. A. (1996): Dynamics of plankton communities in four freshwater lentic ecosystems in relation to varying dominant biota. Poll. Res., 15(3): 287- 291.

APHA (1985): Standard Methods for the Examination of Water and Waste Water, American Public Health Association, New York. 16th Edition.

Banakar, A. B.; Manjappa, S.; Kiran, B. R.; Puttaiyah, E. T. and Ravikumar, M. (2005): Phytoplankton diversity in relation to abiotic factors in Chandravalli tank at Chitradurga, Karnataka. J. Aqua. Biol., 20(2): 25-30.

Chakraborty (1959): A qualitative study of plankton and physico-chemical condition of the river Yamuna at Allahabad. Ind. J. fish, 6(1): 186-208. 
Edmondson, W. T. (1959): Freshwater Biology, John Wiley and Sons Inc. N.Y., 420-494.

Goel (1985): Studies on the limnology of few fresh water bodies in South Western Maharashtra. Indian J.Env.Prot., 5(1): 19-25.

Jayabhaye, U. M.; Madlapure, V. R. and Salve, B. S. (2007): Phytoplankton diversity of Parola Dam Hingoli, Maharashtra. J. Aqua. Biol., 22 (2): 27-32.

Malik, D. S. and Bharti, Umesh (2012): Status of plankton diversity and biological productivity of Sahastradhara stream at Uttarakhand, India. Journal of Applied and Natural Science. 4(1):96 -103 .

Matta, Gagan (2010): "Freshwater: Resources and Pollution" Environment Conservation Journal, 11 (3): 161-169,

Matta, Gagan (2015): Effect of water quality on phytoplankton ecology of Upper Ganga Canal, International Journal of Scientific \& Engineering Research, Volume 6, Issue 2, 762-768.

Matta, Gagan and Uniyal, D. P. (2017): Assessment of Species Diversity and Impact of Pollution on Limnological conditions of River Ganga. Int. J. Water, 11(2): 87-102.

Matta, Gagan; Pandey, R. R. and Saini, K. K. (2015): Assessment of pollution on water quality and phytoplankton diversity in canal system of River Ganga. World Journal of Pharmaceutical Research. Vol. 4(11): 889-908

Matta, Gagan, Gjyli, Laura, Kumar, Avinash, John Machel (2018): Hydrochemical characteristics and planktonic composition assessment of River Henwal in Himalayan Region of Uttarakhand using CPI, Simpson's and Shannon-Weaver Index. Journal of Chemical and Pharmaceutical Sciences. 11(1).

Matta Gagan, Avinash Kumar, Gulshan K. Dhingra, Singh Prashant, Gjyli Laura, Amit Kumar (2018): Limnological assessment of anthropogenic activities of River Henwal. Journal of Chemical and Pharmaceutical Sciences. 11(1).

Matta, Gagan; Kumar, Avinash; Naik, Pradeep K., Tiwari, A.K. and Berndtsson, R. (2018): Eco- logical Analysis of Nutrient Dynamics and Phytoplankton Assemblage in the Ganga River System, Uttarakhand. Taiwan Water Conservancy. 66 (1): $1-12$.

Pahwa, D. V. and Mehrotra, S. N. (1966): Observations in the abundance of plankton in relation to certain hydro-biologicalconditions of river Ganges. Proc. Natl. Acad. Sci., 36 (2):157-89.

Palmer, C. M. (1969): A composite rating of algae tolerating organic pollution. Journal of Phycology, 5:78-82.

Pendase, D. C.; Shastri, Y. and Barhate, V. P. (2000): Hydrobiological study of percolation tank of village Dasane, Maharashtra, India. Eco. Env. And Con., 6(1): 93-97.

Ryder, R. A.; Kerr, S. R.; Loftus, K. H. and Register, H. A. (1974): The morphoedaphic index, a fish yield estimator review and evaluation. J. fisheries Res. Canada, 31: 663-668.

Sarwade, A. B. and Kamble, N. A. (2013): Planktonic quantification in Bharatnagar lake of Miraj tahsil, District Sangli, Maharashtra. Bionano Frontier, 6(1):118-124.

Xie, P.; Iwakum, T. and Fujii, K. (1998): Changes in the structure of a zooplankton community, during a certium (divoflagllate) bloom in a eutrophic fishless pond. J. Plankton Res., 20 (9):1663-1678 